\title{
Working with Indigenous Peoples to foster sustainable food systems
}

\author{
GUeSt EditORial by Kent MULLINIX \\ INSTITUTE FOR SUSTAINABLE FOOD SYSTEMS \\ KWANTLEN PolyteCHNIC UNIVERSITY
}

Published online August 6, 2015

Citation: Mullinix, K. (2015). Working with Indigenous Peoples to foster sustainable food systems

[Guest editorial]. Journal of Agriculture, Food Systems, and Community Development, 5(4), 3-6.

http://dx.doi.org/10.5304/jafscd.2015.054.008

Copyright (C) 2015 by New Leaf Associates, Inc.

$\mathrm{I}_{\mathrm{r}}^{\mathrm{n}}$

n order for sustainable, regional food systems to be so they must embody the vision and aspirations of all

people and communities therein. In Canada, Indigenous Peoples and First Nations are an important, though often marginalized, element of our communities and society (Gray, 2011). Therefore I proffer that sustainable, regional food system planning, advocacy, and action in Canada (and elsewhere) should include the perspectives and support the predilections of Indigenous Peoples and communities. Though there are important, examples of effective efforts to do so (Food Matters Manitoba, 2015; Tu'wusht Project [Vancouver Native Health Society, 2014] in Vancouver; Food Secure Canada, 2015), in my experience working in Western Canada and elsewhere North American, sustainable food system researchers, activists, and others have been substantially remiss in this regard, with a resultant impoverishment of the movement in terms of perspective, inclusivity, and strategy. At the Institute for Sustainable Food Systems (ISFS) at Kwantlen Polytechnic University, an applied research institute that works to advance regionalized food systems by delineating their economic, food self-reliance, environmental stewardship, and community development potentials, we are trying to do otherwise.

To begin the ISFS journey to better understand Indigenous food system perspectives and predilections we recruited Dawn Morrison of the Secwepemc Nation (Interior Salish) to join our research team. A horticulturist and long-time Indigenous food system advocate, Morrison is the founder and current chair of the British Columbia Food System Network Working Group on Indigenous Food Sovereignty (Morrison, 2008). For the past two years she has worked directly with the rest of the ISFS team to advance our understanding of what it might mean to bring together Indigenous food systems thinking with sustainable farming and food systems thinking, as well as the challenges inherent in this pursuit.

Kent Mullinix, Institute for Sustainable Food Systems, Kwantlen Polytechnic University; 12666-72 ${ }^{\text {nd }}$ Avenue; Surrey, British Columbia V3W 2M8 Canada; +1-604-612-1252; kent.mullinix@kpu.ca 
Soon after joining the ISFS team Morrison recruited members for and convened an Indigenous Research Advisory Committee (IRAC). The IRAC is made up of individuals representing areas of focus important to Indigenous Peoples in our region, as opposed to representing organizational, political, or governmental entities. The IRAC has provided guidance and feedback on our work. It is an understatement to say that we have found it critical and enlightening to obtain direct input and feedback from Indigenous Peoples. For example, we have been challenged to think of farming as a colonialist enterprise, as well as to better understand the deep cultural significance of certain foods and traditional foodways.

The ISFS has focused on soil-based agriculture as the foundation of a regionalized, sustainable food systems. We describe our focus generally as small-scale, human-intensive, decommoditized, diversified, focused on community and alternate markets, environmentally and economically sound, reflective of and responsive to diverse cultural predilections, and with commensurately scaled and operated ancillary pre- and postproduction businesses. Working with IRAC however, we were compelled to acknowledge that our focus neglected to include salmon, the "keystone" and iconic food of British Columbia's Coastal Salish Peoples. Despite this acknowledgment we still struggle to incorporate marine elements into our southwest British Columbia bioregional food system design and planning work, due to the political sensitivity and scientific complexity of doing so. The closest we have come, at this juncture, is elucidating some of the potential of incorporating habitat improvement to salmon-bearing waterways in agro-ecosystems and the region's agriculture landscape.

To more fully inform our efforts to include Indigenous perspectives and predilections in our food systems work, Morrison, with the IRAC and others, has focused on assessing and delineating food system predilection and aspirations of Indigenous Peoples in southwest British Columbia (BC). She reminds us that this is no simple endeavor as the Indigenous Nations and Peoples of our region are many and diverse, and that generalizing and speaking for other Peoples is not appropriate. Based on this we are working to develop a framework or matrix whereby food system planning and action in southwest BC can be evaluated based on the food system attributes and outcomes desired by Indigenous Peoples here. We hope this framework might motivate and inform similar food system assessment in other regions.

The ISFS has also been working with the Tsawwassen First Nation (TFN), whose traditional (and now treaty) lands are located on the rich delta of the Fraser River, one of BC's most productive agriculture areas. Last year, at the behest of and in full partnership with the TFN government, we began developing a farm school to be implemented in spring 2015 (Kwantlen Polytechnic University, n.d.). The Tsawwassen First Nation-Kwantlen Polytechnic University (TFN-KPU) Farm School, modeled after our first farm school in neighboring Richmond, BC, is designed and intended to expediently and effectively train TFN citizens (and others) in the art and science of small-scale, alternate market farming. The program, which is conducted over a nine-month period, is composed of approximately 350 hours of classroom teaching and learning complemented by at least 350 hours of experiential teaching and learning on a small, human-intensive, organic market crop, tree fruit and small animal farm. The program culminates with a farm business planning course in which students develop a business plan of their own. Successful completion of the program and business plan qualifies students to access a half-acre ( 0.2 hectare) incubator farm plot and shared equipment for up to four years. During those four years incubator farmers, with the support of TFN-KPU Farm School teachers and staff, have the opportunity to hone their farming and farm business management acumen in a low risk-environment, in preparation for eventually securing their own land for farming independently over the longer term. TFN has about 640 acres (260 hectares) of agricultural land that potentially could be farmed by TFN citizens for their community and the larger Metro Vancouver market.

To initiate the program, TFN matched ISFS's start-up funding and provided 20 acres ( 8 hectares) for the teaching and incubator farm parcels. ISFS developed the curriculum, the teaching and incubator farms and facilities, and oversees the farm school. In addition to production and agricultural science classes, the curriculum also includes a class on Indigenous foods and food systems. Working with TFN we also anticipate developing additional courses and programming that are especially relevant to the Tsawwassen First Nation 
community (for example, traditional food preservation, medicinal plant identification and cultivation, and a children's pumpkin patch). Ultimately we (TFN and ISFS) envision the teaching and incubator farms becoming a community gathering place in addition to an educational facility - the true integration of agriculture, education and community.

The TFN-KPU Farm School operates on a cost recovery basis with a target enrollment of 12 students. Preference is afforded first to TFN citizens and then to other Indigenous individuals. Our inaugural class was over-subscribed with 16 students coming from six Coast Salish Nations (Coast Salish peoples are a group of Indigenous peoples of the Pacific Northwest coast). We view this level of interest as a great success.

In working with TFN I have come to learn that my perspective of sustainable farming as inherently positive may or may not be shared by Indigenous Canadians. It has been communicated to me that for some, agriculture is regarded as a mechanism of colonization. A Tsawwassen Nation Elder told me that when agriculture in their traditional territories was being concertedly developed in the mid-20 th century, the provincial government purposefully excluded Tsawwassen First Nation citizens from receiving support that others were afforded to develop farming expertise and to be part of the nascent agriculture sector. Animosity toward farming and farmers resulted and persists to some extent today. What is more, the pain and destructive impact of Residential Schools (as recent as the 1990's) reverberates through Indigenous and Canadian society (Anishinabek Nation, n.d.; Gray, 2011). Residential schools were a network of boarding schools for First Nations, Métis and Inuit children, funded by the Canadian government and administered predominantly by the Catholic and Anglican churches. The objective was to remove children from the influence of their families and culture and assimilate them into the dominant Canadian culture. I have been told that working in the vegetable gardens at residential schools was one form of punishment some experienced, and therefore for some agriculture is a source of on-going pain and is held in disdain. It has also been expressed to me by Indigenous people that sincere efforts to include Indigenous communities' perspectives and predilections in conceptualization and development of a sustainable regional agriculture and food system may be one means of contributing toward reconciliation (revealing and resolving past wrongdoings) and healing (Truth and Reconciliation Commission of Canada, 2015).

In addition to our partnership with TFN we have also begun discussion with the Lil'wat Nation, whose traditional and treaty lands are north of Vancouver, regarding a partnership to establish and operate a farm school on their lands for their people. Additionally we are now working with the Tr'ondëk Hwëch'n First Nation in Dawson City, Yukon, to develop a business and operations plan for their nascent community farm and farm school. Both of these First Nations, like the Tsawwassen First Nation, see enormous potential for food self-reliance, food security, economic (monetary or other) and community development in engaging in small-scale, alternate-market, and community-focused farming on their lands. Equally important to Tr'ondëk Hwëch'n citizens is the potential of a community farm to offer a safe, healthful environment, respectful of wellness, that provides opportunity for working on their traditional and settlement lands and for a traditional and cultural experience. During an ISFS project working with Carcross Tagish First Nation (CTFN), in the southern Yukon, citizens of that self-governing First Nation also expressed their trepidations and aspirations regarding their food system (Dorward, Kassi, Chiu, \& Mullinix, 2014). They are concerned with food insecurity and the sustainability of their food system going forward. A dominant concern is the loss of traditional knowledge and ways (hunting, fishing, preserving, and gathering) that they want to remain an important part of their food system, and which they wish to pass on to their youth. CTFN citizens also recognize the vulnerability of communities, especially those in the far north, that are highly dependent upon costly, imported foods. As such, CTFN members are looking for ways to become more food self-reliant, create job and income opportunities, and contribute to community health via the production of nutritious, healthy food by the community, for the community. CTFN citizens also envision community food system infrastructure for preservation, processing, and storage. Finally there is recognition that some young CTFN members are interested in community-focused food production.

Community and environmental health and well-being has been central to all sustainable food system 
discourse I have had with Indigenous people, including leaders and Elders. Not once has interest in conventional, commodity agriculture been expressed.

My perception is that most Indigenous people with whom I have interacted regarding farming and food systems, as well as those representing their interests (e.g., planners, resource managers), embrace a perspective akin to "deep sustainability." They operate from the perspective that our health and well-being is entirely interdependent with the health and well-being of Creation and therefore that we, notably inclusive of our food system, must nurture and respect Mother Earth. I see this perspective very much aligned with the sustainable agriculture and food system paradigm and this strengthens my conviction that Indigenous perspectives, communities, and governments can and should play a leading, powerful role in the sustainable agriculture and food system movement. Moreover, if the sustainable food systems we envision are to truly embrace the concept of social equality and justness, then it is absolutely imperative that Indigenous peoples be integral to it. To do otherwise is to perpetuate the imposition of a food system upon this segment of our communities and marginalization of their preferences. We must find a mutual way forward with our food system; it is incumbent on us to foster the circumstance in which this can occur.

\section{References}

Anishinabek Nation. (n.d.). Indian Residential Schools Commemorative Project: About Indian residential schools. Retrieved June 4, 2015, from http://www.anishinabek.ca/irscp/irscp-about-residential.asp

Dorward, C., Kassi, N., Chiu, C., \& Mullinix, K. (2014). Our food security today and tomorrow in Carcross/Tagish First Nation. Richmond, BC: Institute for Sustainable Food Systems, Kwantlen Polytechnic University. Retrieved from http://www.kpu.ca/sites/default/files/ISFS/CTFN\%20Community\%20Food\%20Report 2014.12.16 FINAL\%20 APPROVED.pdf

Food Matters Manitoba. (2015). Resetting the table: A people's food policy for Canada (2nd ed.). Retrieved from http://foodsecurecanada.org/resettingthetable

Food Secure Canada. (2015). Resetting the table: A people's food policy for Canada (2nd ed.). Montreal, Quebec: Author. Retrieved from http://foodsecurecanada.org/resettingthetable

Gray, L. (2011). First Nations 101: Tons of stuffyou need to know about First Nations people. Vancouver: Adaawx Publishing.

Kwantlen Polytechnic University. (n.d.). Tsawwassen First Nation Farm School. Retrieved June 4, 2015, from http://www.kpu.ca/tfnfarm

Morrison, D. (2008). B.C. Food Systems Network - Working Group on Indigenous Food Sovereignty: Final activity report. Vancouver: B.C. Food Systems Network and Working Group on Indigenous Food Sovereignty. Retrieved from http://www.indigenousfoodsystems.org/content/bc-food-systems-network-working-group-indigenous-foodsovereignty-final-report

Truth and Reconciliation Commission of Canada. (2015). Honouring the truth, reconciling for the future: Summary of the final report of the Truth and Reconciliation Commission of Canada. Retrieved from http://www.trc.ca/websites/trcinstitution/File/2015/Findings/Exec_Summary_2015_05_31_web_o.pdf

Vancouver Native Health Society. (2014, August 7). Tu'wusht project [Press release]. Retrieved from http://www.vnhs.net/programs-services/tuwusht-project 